\title{
The construction of USS Atlanta and the Navy seizure of Federal Shipbuilding
}

\section{David F. Winkler}

Cet article constitue une étude sur les efforts syndicalistes pour organiser le travail dans les chantiers navals entre 1940 et 1942 quand l'expansion de la marine nationale américaine exigeait un accroissement de l'efficacité de production. Le sujet est la construction du croiseur USS Atlanta aux chantiers Federal Shipbuilding dans le New Jersey, qui a été interrompue par une grève menant à une impasse entre direction et les travailleurs récemment organisés. La marine nationale a saisi le chantier en août 1941, et, tout en observant une stricte neutralité sur les questions de travail, a mis en ouvre des mesures de sécurité de travail qui ont atténué les tensions. La construction de l'Atlanta a été achevée en décembre, en avance de la date prévue, et ceci malgré l'interruption du travail. La réponse patriotique des travailleurs à l'attaque japonaise sur Pearl Harbor le 7 décembre 1941 a permis au gouvernement de restituer le chantier à ses propriétaires début janvier 1942.

Prior to World War II, the War and Navy Departments procured armaments through competitive bids from multiple suppliers in order to lower costs. In the case of shipbuilding, the Navy not only sought to play contractors against each other, but also against the Navy's government-owned shipyards. To be able to compete successfully for contracts, shipbuilding corporations sought to lower production costs by employing cheap non-union labor.

With naval ship contracts far and few between during the 1920s and the early years of the Great Depression, commercial shipyards were able to easily fend off unionization attempts as workers, grateful to have jobs, understood they could be readily replaced. However, with the mobilization for war, labor became a commodity that was in demand as the yards scurried to fill a flood of orders placed by the government. Union organizers were able to leverage the shipyards' need to hire skilled workers, especially welders, to achieve recognition.

At Federal Shipbuilding in Kearny, New Jersey the Industrial Union of Marine and Shipbuilding Workers of America (IUMSWA) would achieve recognition and worked towards the goal of making the Kearny facility a closed shop. With management opposed, the union waged a strike in August 1941. Because of the important need to get ships such as the light cruiser Atlanta out from the building ways to join the fleet at a 
time when German U-Boats were devastating merchant shipping in the North Atlantic, the Navy seized the shipyard and successfully resumed construction.

The Navy Department's secretary, Frank Knox, was a pro-business Republican. Could the union, having the support of the National Labor Relations Board and National Mediation Board, work through the Navy to establish Federal Shipbuilding as a closed shop?

We will never know. In the end, patriotism trumped union militancy. With the attack against Pearl Harbor, union leaders did not want to be seen as aiding and abetting the enemy through work stoppages on war material production lines. Furthermore, the salary needs of the workers the union represented were adequately met because there was more than enough work for both the corporate and government owned shipyards in the managed wartime economy. There would be only one other case where the Navy would seize a shipyard during World War II, which was the Los Angeles Shipbuilding and Drydock Corporation in San Pedro in 1943. However, the issue in San Pedro was gross management incompetence. After seizing the facility and taking an inventory of assets, the Navy turned the facility over to Todd Shipbuilding which operated the shipyard until 1989.

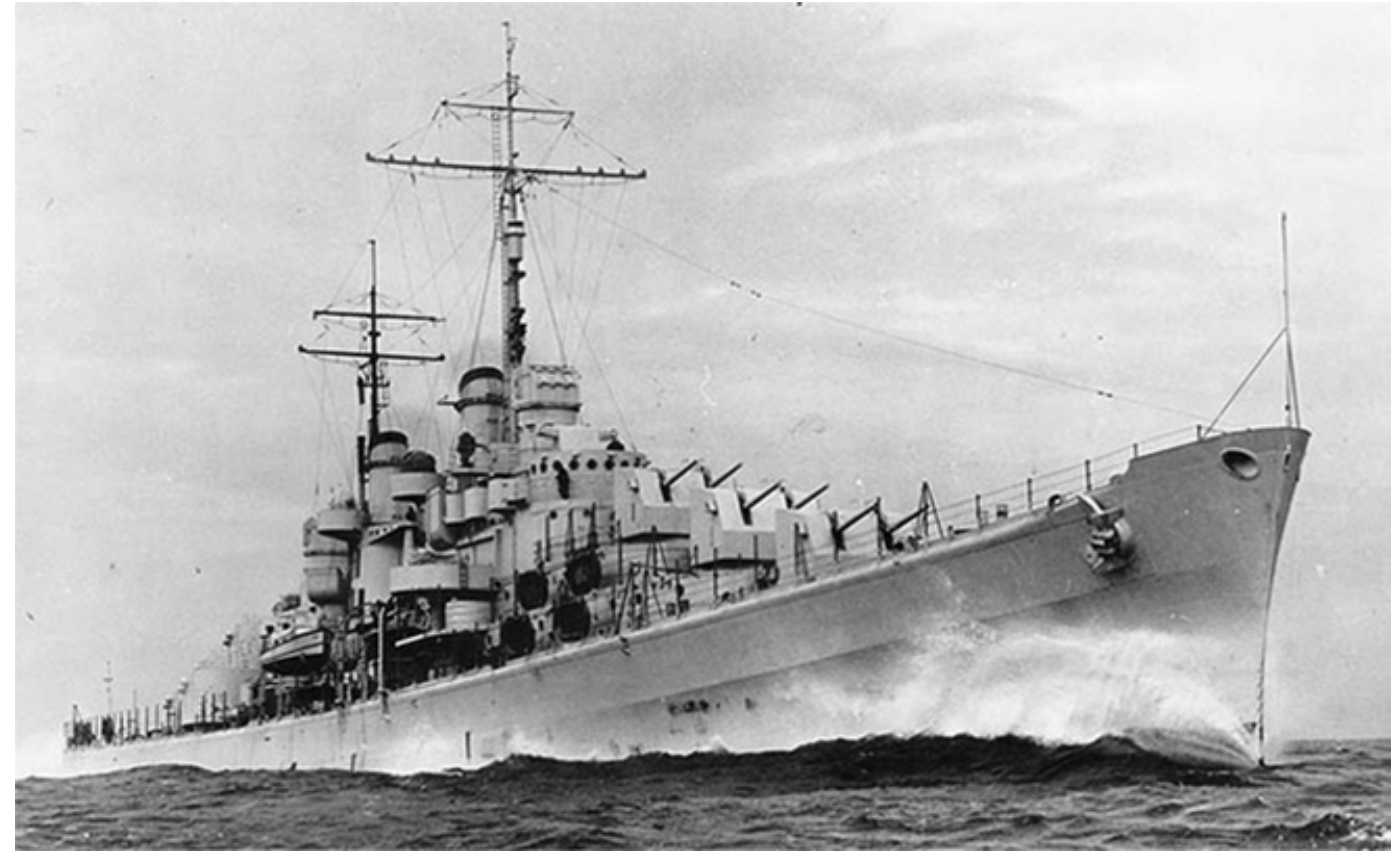

Illustration 1: The light cruiser USS Atlanta (CL 51).

USS Atlanta (CL 51) was the third American warship named for the capital of Georgia. A combination of international and domestic events in the mid-1930s created the requirement for the United States Navy to build a new type of light cruiser.

The ship design that eventually evolved to become the Atlanta class had its roots in the naval arms control regime of the era. Talks in London in 1936 produced an 
informal understanding that future cruisers would displace no more than 8,000 tons and carry armament no heavier than 6-inch guns. Navy planners understood they could proceed with building a new class of cruisers as the 1934 Vinson-Trammell Act authorized the Navy to build ships to replace obsolete vessels. The Omaha class, with the lead ship launched in 1919, was approaching block obsolescence. ${ }^{1}$

The chief of naval operations (CNO), Admiral William H. Standley, in December 1936 decided that ten cruisers of 5,000-7,000 tons should be built and the General Board asked the Preliminary Design office to draft some proposals. It was assumed that these ships would be armed with 6-inch/47 guns, ${ }^{2}$ however, the designers put forward sketches that also featured mounts for 5 -inch/ 38 caliber. Of the nine sketches put forward, one came close to the final design of the Atlanta class.

A General Board memo dated December 1937 recommended going ahead with a class of 5-inch gun cruisers but to limit the class to four ships, with the thought that development of the 6-inch mount would facilitate a follow on ship class. Standley's replacement as CNO, Admiral William D. Leahy, signed a letter specifying the design requirements on 2 March 1938. The Atlanta class preliminary design was completed in July $1938 .^{3}$

The Navy sought bids for hulls 51 and 52 (Atlanta and Juneau) from Bethlehem Steel Company (Shipbuilding Division) at Quincy, Massachusetts and from Federal Shipbuilding and Dry Dock Company at Kearny, New Jersey. When the bidding deadline passed on 15 February 1939, the Navy had received only a bid from Federal proposing a cost of $\$ 15,950,000$ for one ship or $\$ 14,200,000$ if both ships were awarded to the New Jersey shipyard. Bethlehem Steel did bid for the next two ships of the class. The Navy awarded the contracts for Atlanta and Juneau to Federal Shipbuilding for \$12,226,000 per ship on 10 April 1939 and the contract was signed 15 days later with a delivery date set for 1942. While Federal Shipbuilding and Drydock Company would build the Atlanta and Juneau, Bethlehem Steel earned the contract for the San Juan and San Diego. ${ }^{4}$

Located on the west bank where the lower Hackensack River empties out into Newark Bay in northern Jersey, the Federal Shipbuilding and Dry Dock Company's shipyard was one of America's most modern. Constructed during World War I as a United States Steel subsidiary, the yard built small merchant ships for the Allied cause. With the conclusion of the war and cancellation of contracts, the shipyard let go of thousands of workers. Following the onset of the Depression, what little work there was vaporized and the yard could only sustain a workforce of 600 .

1 Norman Friedman, U.S. Cruisers: An Illustrated Design History (Annapolis: Naval Institute Press), 217-218.

2 To clarify naval gun nomenclature, 6/47 means the gun barrel is six inches in internal diameter (bore) and the length of the barrel is 6 inches x 47 equaling 282 inches or twentythree and a half feet.

3 Ibid., 232-233.

4 Navy Department Press Release of 15 February 1939, Atlanta Pre-commissioning folder, Ships History Branch, Naval Historical Center, Washington, DC [NHC]; Fact sheet, Atlanta folder, ibid. 
The election of President Roosevelt certainly benefited the shipyard. In 1933, the shipyard received contracts to build Mahan class destroyers using funds made available through Roosevelt's National Industrial Recovery Act. A year later, the Navy used funds appropriated through the Vinson-Trammell Act of 1934 to contract for the heavy destroyer USS Somers. As these ships joined the fleet, the shipyard won additional contracts. By 1936, some 3,000 workers fabricated new merchant ships and the yard earned contracts to build Navy destroyers. With its expanding work force, Federal Shipbuilding earned kudos for building ships quickly and efficiently. ${ }^{5}$

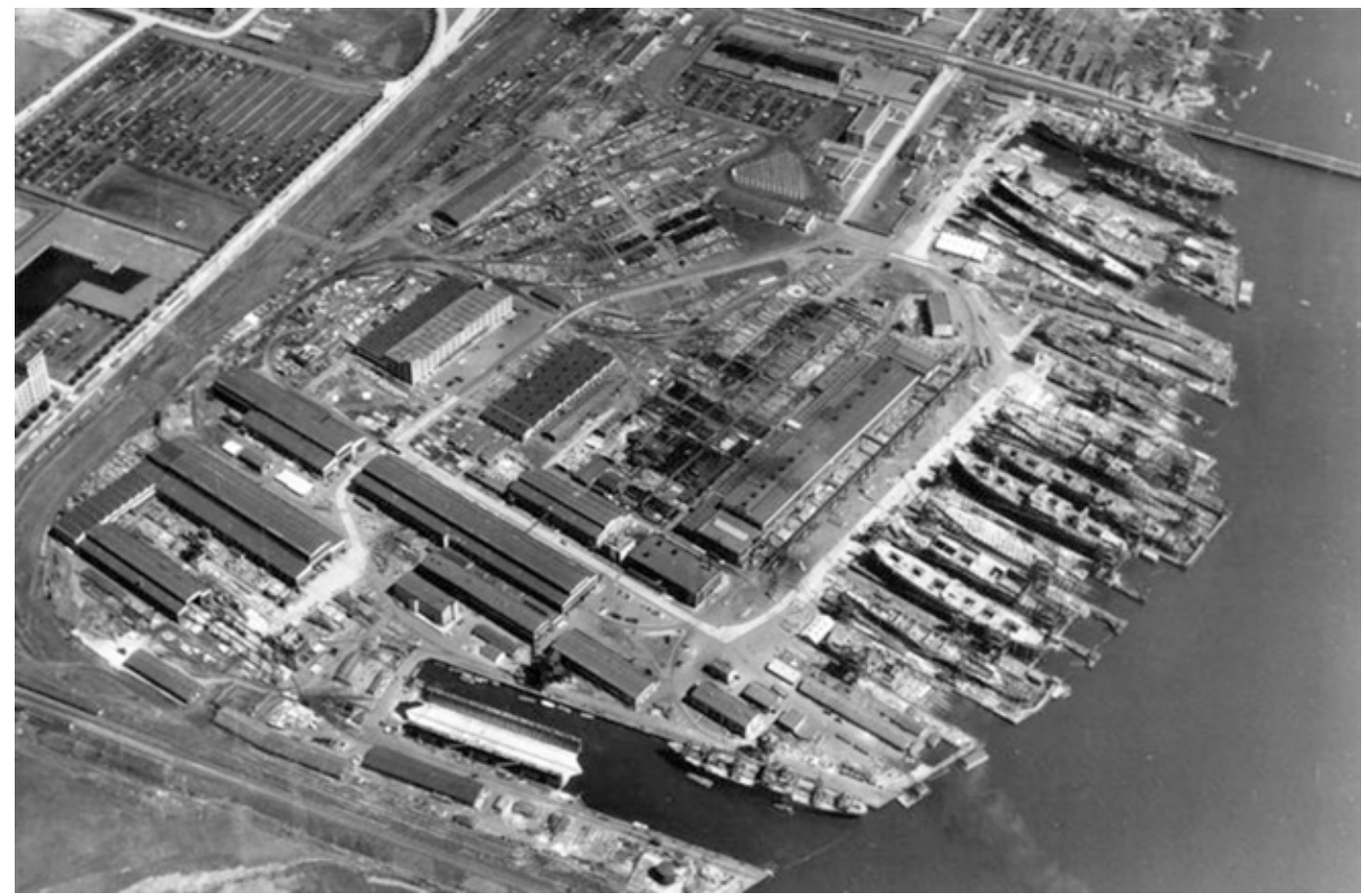

Illustration 2: Federal Shipbuilding in Kearny, New Jersey (author's collection).

While appearing to be a stellar operation on the surface, Federal Shipbuilding management's relationship with its workforce made the industrial facility a prime candidate for union organizers. The emergence of unionism at the shipyard during the 1930s eventually would affect the timetable of Atlanta's commissioning in 1941.

United States Steel had fervently opposed the unionization of its workers. Antiunion policies extended down to Federal, as well as the shipyards of other corporations along the eastern seaboard. Other challenges confronted union organizers. The strength through unity message found few takers during the early period of the depression, when workers felt grateful to have work at any wage. In North Jersey, local politicians also threw obstacles in the way. Across the Hackensack River in Jersey City, Mayor Frank

5 “Shipyard Union calls 16,000 out on Defense Jobs,” New York Times (7 August 1941), 1, 12. 
Hague ran an entrenched urban political machine that looked dimly at union activism. ${ }^{6}$

Yet Mike Smith, the IUMSWA organizer at Federal Shipbuilding, was aided in his efforts by several developments. First, the new CEO of United States Steel, Myron Taylor, sought labor peace. At Federal Shipbuilding, this meant union organizers on the company payroll were not terminated, as they were at other shipyards. Second, Federal Shipbuilding's company "union" was neither popular among workers nor effective. Management did not actively seek out employee involvement in company committees. When worker representatives approached the company about pay increases in early 1935 , they were firmly rebuffed. Third, shipyard's shop foremen, nicknamed "Snappers," bullied workers and demanded they perform in unsafe conditions that led to a high accident rate, claiming the lives of several workers and injuring many more.

The increasing size of Federal Shipbuilding's workforce was another factor that favored unionization. New workers did not feel a particular loyalty to the company. A fifth factor involved the standardization of hull designs that called for the extensive use of welders. Federal Shipbuilding, desperate to find skilled welders, readily hired individuals who had been let go at other shipyards because of their union activism. Federal Shipbuilding's layout also was a factor that facilitated Smith's efforts. Its modern design enhanced the flow of production. The plate shops, located at the rear of the building ways, served as a gateway for components from the adjacent trade shops. As the hub of ship production, the plate shops would double as a nexus for union organization.

The leftist reputation of the independent IUMSWA caused many of the older conservative workers to initially shun the organization. However, when the CIO brought the union under its umbrella in late 1936, the union began to be seen as mainstream. Finally, Smith's talents as an organizer contributed to the union's ultimate success. His roots as a Scotch-Irish Roman Catholic shielded him from being tagged a Communist and his patience and willingness to listen to workers earned him respect. By February 1937, he had enrolled enough workers to call for an open meeting.

On 26 February, over 500 Federal Shipbuilding workers met at Jersey City's Ukrainian Hall. There they heard IUMSWA President John Green, who had successfully led the IUMSWA drive to organize the New York Shipbuilding Yard in Camden, deliver a fiery speech attacking Mayor Hague's anti-unionism. Despite police surveillance, the union added another 100 members to its rolls. Smith held more meetings within the communities around Kearny and targeted the shipyard's riveters, who sought higher wages, to obtain the critical mass needed to charter a local. Smith succeeded. More than 1,000 workers in attendance at a 15 March meeting elected officers and chartered Local 16 of the IUMSWA. Within a month, the union claimed it had signed up eighty percent of the Federal Shipbuilding workforce and approached management about contract negotiations.

The newly formed Local 16 increased its leverage when it ran candidates to fill vacancies on the board of the company's union and won all of the positions, even

6 David Palmer, Organizing the Shipyards: Union Strategy in Three Northeast Ports, 19331945 (Ithaca: Cornell University Press, 1998), 106. 
unseating the incumbent president. The new officers then passed resolutions recognizing Local 16 as the union representing the shipyard workers and the second resolution dissolved their organization.

Given the impressive success of the union organization effort, Federal Shipbuilding President Lynn H. Korndorff met with representatives of Local 16 on 26 April to begin negotiations. On 6 May, the union put forth a list of demands, including recognition of Local 16 as the sole bargaining agent for the workers. At six-foot sixinches tall, Korndorff was described as "physically intimidating." "He made it clear from the start," recalled welder Nat Levin, "that no one was going to tell him how to run his company, and that the officers of United States Steel in Pittsburgh didn't give a hoot how he runs Federal so long as it makes money for them..."7 Within two weeks, employeremployee relations had soured with the union staging sit-down strikes and the management firing strike leaders and conducting lock-outs. On 18 May, the workers voted to strike and picketers positioned themselves around the entrances. Within three days, Korndorff yielded and agreed to allow Local 16 to be the exclusive bargaining agent. He would not agree to allowing Federal Shipbuilding to be a total union shop or to a general wage increase, but the union was initially satisfied with the establishment of a minimum wage and formal grievance procedures. ${ }^{8}$

With its minimum demands met, Local 16 would continue over the next three years to apply pressure on Korndorff through what historian David Palmer labeled "a continuous guerrilla war for their rights on the job." ${ }^{\prime \prime}$ In March 1940, Local 16 sought National Labor Relations Board recognition by holding an election. The union won 4,683 votes of 5,712 votes cast. However, while the majority of the workers were delighted to have Local 16 represent them, only a minority of them actually were dues paying members. Naturally, these workers who benefited from the presence of the union frustrated the local leaders by ignoring their urgings to sign on. Thus Local 16 hoped that they could negotiate a contract that made union membership a condition of employment at Federal Shipbuilding. On this issue Korndorff would not yield. ${ }^{10}$

In the meantime, preparations went ahead to build a cruiser on Kearny's Building Way Number 8. On 22 April 1940, the keel, the backbone of the ship, was laid and soon steel ribs began appearing fore and aft. ${ }^{11}$

While management-union relations remained hostile, the mutual enmity must have been tempered by events overseas. During the previous September, Germany had quickly invaded and conquered much of Poland, leaving Eastern portions to the Soviet Army. Then on 10 May 1940, seventy-five Wehrmacht divisions invaded Holland, Luxembourg, and Belgium. On 14 June, German troops marched into Paris. France formally surrendered eight days later, leaving Britain and her Empire alone to stand up

7 Ibid., 135.

8 Ibid., 108-120.

9 Ibid., 122.

10 Ibid., 151-151.

11 Ship's Data Card, Atlanta file, Ships History Branch, NHC. 
against Hitler. Although remaining neutral, through actions such as the "Destroyers for Bases" agreement of September 1940 and, especially, the Lend-Lease Act of March 1941 the United States clearly supported Great Britain. ${ }^{12}$

Likewise, in the ongoing war between Japan and China, neutral America tilted strongly in favor of China against Imperial Japanese expansion. During the summer of 1940, the United States began to ban the export of what would become a growing list of materials to Japan. Conversely, American arms and materials found their way into the hands of Chinese armies and Americans "volunteered" to serve as advisors and, in some cases, fly against Japanese air forces over the mainland. ${ }^{13}$

Three days after the Germans marched into Paris, Carl Vinson, chairman of the House Naval Affairs Committee, introduced another bill calling for a twenty-four percent expansion of the fleet. This time the legislation moved quickly and by the time the president signed "The Two Ocean Navy Bill" in mid-July, the expansion had been upped to seventy percent. ${ }^{14}$

Federal Shipbuilding and Dry Dock Company signed contracts with the Navy to build additional destroyers, cruisers, troop transports, and cargo ships and construction accelerated on the destroyers and cruisers currently under contract. With work on Atlanta ahead of schedule, plans progressed for the ship's christening and launching ceremony. The Mayor of the city of Atlanta nominated Margaret Mitchell, author of Gone With The Wind, to be the sponsor of the ship. The Navy welcomed this but declined a suggestion that the ship be christened with a large bottle of Coca-Cola. ${ }^{15}$

Following the German invasion of the Soviet Union in June 1941, Local 16 immediately pledged to refrain from strikes for a period of two years. The pledge was part of an Atlantic Coast Standards Agreement that had the approval of both the company and the union and the blessing of Secretary of the Navy Frank Knox, Emory S. Land of the Maritime Commission, and the Office of Production Management.

However, while the accord boosted wages by twelve percent, the issue that continued as a sticking point was Local 16's demand for a closed shop and the reclassification of some of the jobs within the shipyard. The union had an important ally in its effort as the dispute had been considered by the Defense Mediation Board in late July and the board recommended the adoption of a modified union shop with grievance boards to be convened to address the reclassification issues. Ideally, Local 16 would have preferred a ruling making the Kearny shipyard a closed shop, meaning all workers there had to be union members. The mediation board recommendation represented a major leap towards that goal, as the modified union shop arrangement required the company to fire any union members who allowed their dues to lapse. While non-union

12 C.L. Sulzberger, World War II (Boston: Houghton Mifflin Co., 1966), 32-38.

13 Ibid., 64.

14 Ibid., 282-283.

15 Correspondence between Captain Bidwell and Mayor LeCraw, 2 May to June 1941; Admiral C. W. Nimitz memorandum to Bureau of Ships, 8 June 1941, Atlanta Pre-commissioning folder, Ships History Branch, NHC. 


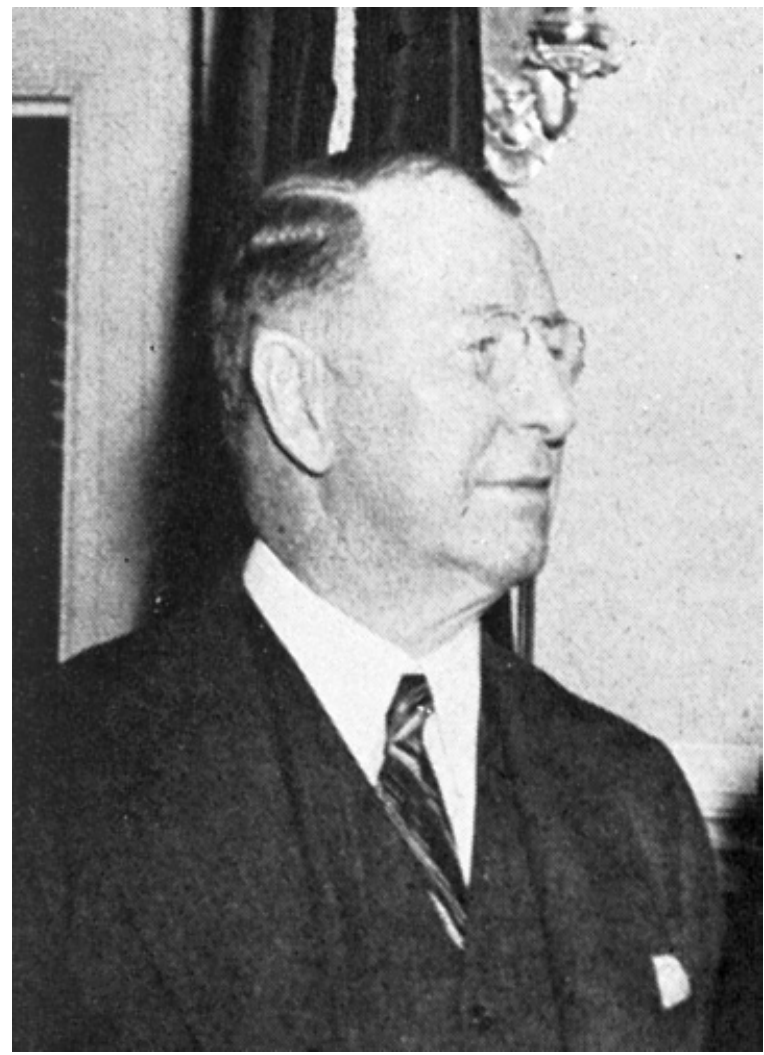

Illustration 3: Frank Knox (1 January $1874-28$ April 1944), Secretary of the Navy. workers could still work at the shipyard, the ruling, if implemented, would virtually guarantee Local 16's ability to retain its current strength as it sought to recruit the non-members. Lynn Korndorff saw the recommendation as unjust. Why should his company be forced to collaborate with the union to enforce union membership?

With inaction on Federal Shipbuilding's part, 6,000 workers packed into Newark's Mosque Theater on the evening of Sunday, 3 August, and they authorized Local 16's leadership to call a strike. Union leaders met with company officials the next day but the talks failed. Union Vice President Peter Flynn claimed "the company took a fence straddling attitude and we haven't heard from them since." Countering Flynn's charge, shipyard president Korndorff accused the union of a "clear and unjustifiable breach."

The 124 member executive board of Local 16 met and voted unanimously to call a strike after several hours of discussion. Consequently, when the 3,000 workers left to go home after the final shift of 6 August, the midnight shift was not there to relieve them. Instead, 250 picketers appeared at the yard's front gate facing U.S. Highway 1. Overall, the job action affected 16,000 workers. The union did allow office workers, Navy personnel, and maintenance workers through the lines. Watched by police detailed from Kearny and Hudson County, the workers protested peacefully. ${ }^{16}$

Historically, in job actions against United States Steel and its subsidiaries, the government would step in on behalf of management. However, when Korndorff flew to Washington on the afternoon of the strike's first day, he did not receive a sympathetic reception from Sidney Hillman at the Office of Management and Production and officials at the Maritime Commission. Korndorff hardly gained any additional sympathy when he spurned a union offer to provide workers to allow the planned 9 August launching of the Atlanta to occur. The embattled shipyard president declared that the event would have to

16 “Shipyard Union calls 16,000 out on Defense Jobs," New York Times (7 August 1941), 1, 12. 
be delayed indefinitely. ${ }^{17}$

Union members were buoyed when on 8 August Acting Secretary of the Navy Ralph Bard, after consulting Hillman and Emory, appealed to Federal Shipbuilding and Dry Dock Company to accept the recommendation of the National Mediation Board. Not everybody in the government sided with the strikers. Local draft boards in Kearny and Jersey City that had given many of the workers deferments due to their vital contributions to the defense industry, withdrew the deferments and prepared to send out draft notices. ${ }^{18}$ However, even here the union drew the upper hand as Brigadier General Lewis Hershey, the National Director of the Selective Service, ordered local draft boards to refrain from reclassifying the strikers.

With Korndorff unyielding, speculation rose about presidential intervention. In New Jersey, Local 16 called for the Navy to take over the yard. However, the president was not in Washington; newspapers reported he was taking an "Atlantic cruise." With the situation deteriorating further in Europe as Soviet Armies retreated, President Roosevelt, embarked on the cruiser Augusta, arrived at Argentia Bay, Newfoundland. There he met with Winston Churchill, who arrived on the battleship Prince of Wales, for four days of talks that would lead to the draft of the Atlantic Charter, calling for the defeat of the Axis served as a founding document for the post-war United Nations. The strike in Kearny would have to wait. ${ }^{19}$

While the commander in chief met with his British counterpart, Navy, Maritime Commission, and Office of Production Management officials discussed options and began planning for a government takeover of the shipyard should the company and union fail to make peace. Such a takeover would not be unprecedented. Two months earlier, citing language contained in a 27 May 1941 proclamation declaring a national emergency, the government dispatched 2,500 soldiers with fixed bayonets to seize an aircraft factory beset by labor strife in California. In that case Uncle Sam returned the plant to North American Aviation after a collective bargaining agreement was signed between the company and CIO local. By contrast, the official anticipated that the takeover of Kearny shipyard would be long-term.

In making his case to maintain an open shop, Korndorff argued that the issue "is whether the American worker shall be permitted to retain his traditional freedom of action and be allowed to determine for himself whether or not he shall belong to a labor union." ${ }^{20}$ Although he felt on principle he was on solid ground, clearly the meetings in Washington shook his confidence about the ultimate outcome. Sensing that President Roosevelt would take action upon his return that would be unfavorable to Federal Shipbuilding, Korndorff decided to change course. On 11 August, he sent a telegram to the secretary of the navy offering the plant to the government, repeating his arguments about the injustice of the Mediation Board's decision but also citing the national defense

17 "Shipyard Seizure by U.S. suggested at Kearny Strike," New York Times (8 August 1941), 1.

18 Ibid.

19 Sulzberger, 66-67; “Navy Demands Ship Strike End,” New York Times (9 August 1941).

20 "Navy Operation of Kearny Yard asked by Owner," New York Times (12 August 1941), 1, 12. 
as being of far greater importance than the welfare of the company. ${ }^{21}$ On the next day in the nation's capital, Korndorff met with Secretary of the Navy Knox to discuss his telegram. After two meetings, the secretary told reporters that "no decision has yet been reached" on whether the shipyard would come under government control. ${ }^{22}$

Back in New Jersey, Governor Charles Edison, a former navy secretary, was appalled by the developments that led to both the company and the union calling for federal takeover. Citing such an action as antithetical to the American capitalist system, Edison sent telegrams to all parties offering his good offices to settle the strike and keep the shipyard in private hands, arguing that a settlement that put the yard in government hands was "fraught with the gravest danger to labor, industry, and all other citizens of the United States." ${ }^{23}$ Reading between the lines, the state's chief executive was really concerned that New Jersey stood to lose tens of thousands of dollars in corporate taxes.

The governor's pleas fell on deaf ears as the takeover bandwagon moved forward. At Secretary Knox's direction, legal advisor Adlai Stevenson drafted a presidential executive order for seizure and then rushed to Maine to meet the presidential party disembarking from the Augusta at Portland.

However, the president refrained from signing the order. Returning to the White House, on 19 August Roosevelt issued direct appeals to union leader John Green and company president Korndorff to put the national welfare ahead of their dispute and resume work at the shipyard. Although the president's intervention forced the opposing parties back to the negotiating table, Green and Korndorff refused to give way on the modified maintenance issue that plagued the talks from the start. ${ }^{24}$

Finally, on 23 August, President Roosevelt signed the executive order authorizing the Navy's seizure of the shipyard. In the order, blame was placed at the feet of the company's management for its failure to abide by the Mediation Board's recommendation. Ironically, the press release announcing the seizure failed to state if the Navy would operate the plant in accord with the Mediation Board's decision. If the Navy did abide, as it was assumed, it would appear to be a departure from long-standing policy not to take sides between labor and management. ${ }^{25}$

On the afternoon of the $23^{\text {rd }}$, Stevenson hosted a meeting with senior Navy officials and counsel to discuss how the Navy should handle the Mediation Board ruling. The consensus was that Navy would "observe the wage rates, hours, and working conditions prevailing immediately before the stoppage of work, subject to modifications that had been agreed upon; that having no instructions on the Mediation Board question,

21 Ibid.

22 "Edison Asks U.S. Not to Seize Yard at Kearny; Will try to End Strike," New York Times (15 August 1941), 1, 15.

23 Ibid.

24 William H. Lawrence, "Stop Kearny Row, President Pleads," New York Times (20 August 1941).

25 Vice Admiral Harold G. Bowen, USN (Ret.), Ships, Machinery, and Mossbacks: The Autobiography of a Naval Engineer (Princeton: Princeton University Press, 1954), 208-209. 


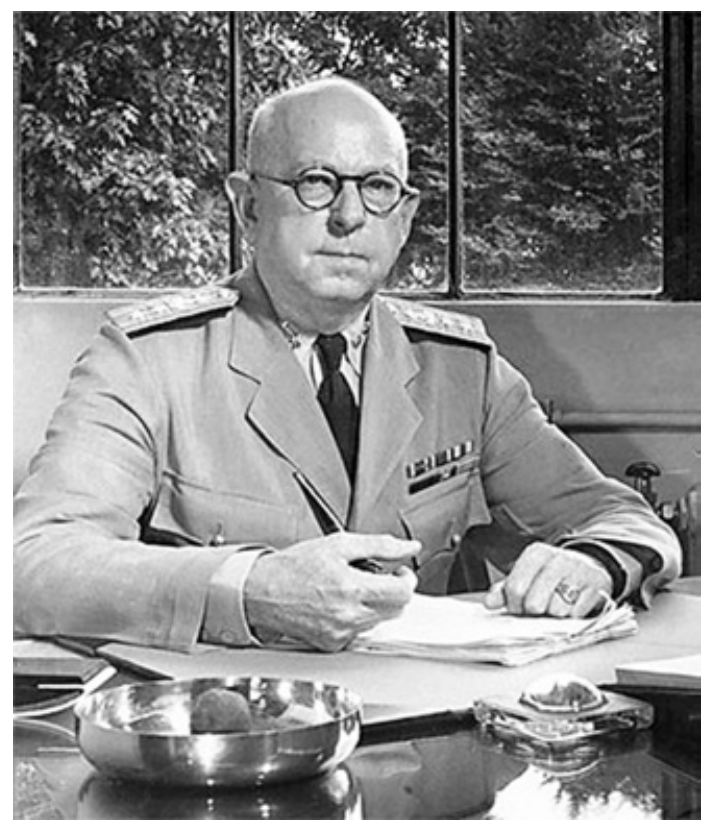

Illustration 4: Rear Admiral Harold G. Bowen (1883-1965.) it was decided to make no commitments in that respect. ${ }^{\circ 26}$

Both the union and the company pledged to cooperate with the government, consequently, there was no need to send in military forces to seize the yard. Instead, Rear Admiral Harold G. Bowen was sent to New Jersey to replace Korndorff as the head of the yard. $^{27}$

A graduate of the U.S. Naval Academy class of 1905, Bowen had served mainly in engineering officer billets in warships and in shore establishments. During the 1920s and 1930s, the Navy assigned him to duties of growing responsibility at Navy shipyards. In 1935, he was promoted to rear rdmiral and appointed chief of the Bureau of Engineering. Under his tenure, new construction warships, such as the Atlanta, were being powered by high-pressure boilers and high speed reduction turbines.In 1939, Bowen became Director of the Naval Research Laboratory and oversaw atomic research and radar development. In this position, he also served as technical aide to the Secretary of the Navy. Well acquainted with Bowen's abilities, Secretary Knox tapped him for the takeover. ${ }^{28}$

The question not addressed in the executive order, was whether the Navy should abide by the Mediation Board's recommendation. In a Saturday night meeting with Knox's special assistant, Adlai Stevenson, and other senior Navy officials, Bowen learned that under Navy management, the contract previously negotiated with Federal Shipbuilding would be maintained. Implementing the Mediation Board's recommendation was seen as taking sides in an ongoing dispute and was to be avoided. ${ }^{29}$

On the train trip up to New Jersey on the morning of Sunday 24 August, Bowen met with his staff. "We had these discussions all the way up from Washington, anticipating as we did trouble with the strikers and expecting no trouble with management." ${ }^{30}$ Much to Bowen's chagrin, when he arrived at the yard in a station

26 Idid., 209.

27 Frank L. Kluckhorn "U.S. Takes Over Kearny Shipyard, Open Tomorrow," New York Times, (24 August 1941), 1, 17.

28 "Vice Admiral Harold Gardiner Bowen" biography, Special Collections, Navy Department Library, Washington, DC.

29 Bowen, 208-209.

30 Ibid., 209. 
wagon to assume control, smiling picketers at the gate, waving American flags, opened a passage to assure the admiral access to the yard. Once inside, Bowen and his party waited briefly in the vice president's office for Korndorff to appear.

In the initial discussions, Korndorff balked, as if the seizure of the plant was still negotiable. He then argued that it would take at least two weeks to get the shipyard back in operation. With the late arrival of Under Secretary James Forrestal, Korndorff relented. Bowen explained his orders called for him to begin operating the shipyard immediately. He stated his intention to meet with the supervisors and foremen the next morning and to have the yard fully opened on Tuesday. ${ }^{31}$

Bowen then met with IUMSWA president John Green who wished to extend his union's support to open the plant. Bowen "thanked Mr. Green and assured him that fair and equitable treatment would always be afforded to the workers in the plant." ${ }^{32}$ Bowen's industrial relations assistant, Daniel Ring, then met with Local 16's Executive Committee. Ring explained that Bowen had not received instructions to enforce union maintenance. However, the Executive Committee welcomed the change in leadership. Shortly afterwards the picketers joyfully ripped up their signs as the union voted to end the job action. Preparations began to reopen the yard on Monday morning and have nearly all of the workers back on Tuesday to pick up their welding torches and rivet guns and recommence work on the Atlanta, Juneau and the destroyers and merchant ships under contract. ${ }^{33}$

Bowen elected to retain most of Federal Shipbuilding's management team, with the exception of Korndroff and his inner circle. To audit the books, the Navy hired Arthur Andersen and Company. Bowen then began to implement "Navy management" in the day-to-day operation of the plant, taking a "hands on" approach, visiting the shops to meet with the supervisors, foremen, and the workers. ${ }^{34}$

Although the workers went back to work, the strike had impeded the progress of Atlanta's construction in more ways than just time lost. Arriving the day after the Navy assumed control of the shipyard, the assistant gunnery officer, Lieutenant Lloyd M. Mustin, gazed at the gunmounts, which had been delivered to the yard and had been left exposed to the hot summer humidity and thunderstorms. "There was a lot of rust in critical areas, things of a sort the shipyard didn't even know how to cure. I could see we were eventually going to have to do it ourselves and eventually we did." ${ }^{35}$

"Ourselves" meant, of course, the ship's crew. On an almost daily basis, sailors showed up in Kearny with orders in hand. Some had transferred from other Navy ships

31 Ibid., 210-211; "Bowen Daily Dairy," Box 9, Records of the officer in charge of operating the Federal Shipbuilding and Drydock Company, Kearny, NJ, RG 80.8.1, National Archives and Records Administration [NARA], New York.

32 Bowen, 211.

33 "Knox Aide Seized Kearny Shipyard, New York Times (25 August 1941), 1, 9.

34 Bowen, 214-215.

35 Vice Admiral Lloyd M. Mustin, USN (Ret.) interview by Mason, U.S. Naval Institute, Washington, DC. 
or shore stations while most had been in the Navy for less than a year, having attended Navy basic training and, in many cases, further training at Navy technical schools.

For Mustin and the other members of the crew who had received early assignments, 6 September proved a memorable day as Margaret Mitchell arrived to christen America's newest cruiser. Preparations for Atlanta's slide down the run had begun on 12 May with the application of stearine lubricant on the run beneath the cruiser's keel. A three-eighths- inch film was applied on the run from amidships forward and the coat increased in thickness to half an inch from amidships aft. A few days later, workers laid another half inch of "launching grease" atop the stearine. On 28 July, a diver greased and covered the underwater portion of

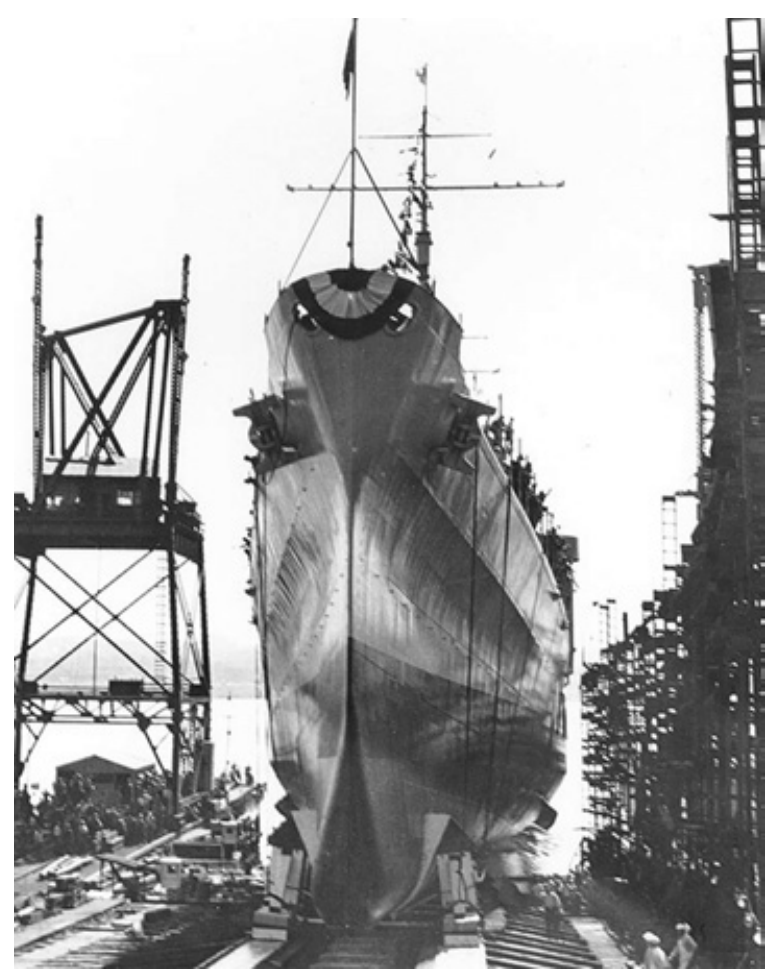

Illustration 5: The launching of the USS Atlanta. the run leading out from Building Way No. 8. In total, 19,600 pounds of lubricant was applied to the run. On the day prior to the launch, a diver then waded into the Hackensack to remove the protective coverings. As he performed this chore, other yard workers began removing every other keel block from beneath the cruiser.

Preparations continued prior to sunrise on 6 September. Beginning at 0400, workers removed grease covers and methodically pulled away the remaining keel blocks and supports, called bents, away from the hull that sported a light gray coat above the waterline and a coat of black anti-fouling paint below. At 0900, a thorough inspection was made to assure watertight integrity. Yard workers closed off all sea openings and shut interior hatches from the second deck aft and below.

Arriving VIPs could see that only two cradles, fashioned out of 200 tons of yellow pine timber, kept the 542 foot-long ship upright in place. Decorations were modest. Yard workers draped a red, white, and blue bunting over the bow and strung up signal flags from the forecastle to the top of the mast. Attendees joining Mitchell included the governor and Mrs. Edison, Under Secretary of the Navy James V. Forrestal, Rear Admirals Bowen and Edward J. Marquart of the New York Navy Yard. For Edison, the launching must have been gratifying as the ship's design was conceived and evolved during his tenure as secretary of the navy.

The New York Times described the festive ceremony noting that Miss Mitchell 
wore "a black crepe dress with white lace collars and cuffs, black flat-heeled shoes and black silk stockings" along with "a pink, off-the-face hat, and a diamond ring, a wrist watch and pearl earrings." The author then grasped the bottle of champagne "much as she would have held a baseball bat" and "cracked it squarely and neatly against the ship's knife like prow, spattering most of the frothy contents well over the hard steel."

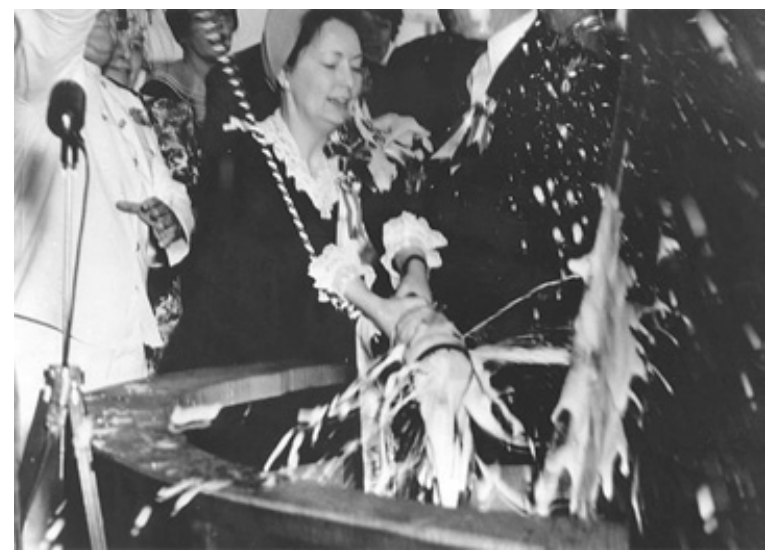

Illustration 6: Margaret Mitchell, author of Gone With The Wind, the sponsor of the ship.
The bubbly splattered, triggers were released and the cruiser then began a slow descent down the ways, picking up speed as she backed into the murky waters of the Hackensack. On board, 181 men, the majority being shipyard workers, rode with the ship as she reached a speed of 20 feet per second before the stern splashed into the river. Loud applause broke out and horns sounded. Afloat, Atlanta continued to back out until the stern rested some 750 feet from the end of the run. Four tugs saddled up against the cruiser and workers struggled to drop the two cradles from beneath the hull. Once free of the cradles, the tugs pushed the ship bow in to berth two in the finishing basin to continue the installation of weapons and other equipment. ${ }^{36}$

Meanwhile, the launching party capitalized on another Atlanta connection as the local Coca Cola bottling plant, located across from the yard, hosted a lunchtime reception where Lieutenant Commander Norman W. Sears, the acting commanding officer of the pre-commissioning unit and future first lieutenant, accepted a silver punch bowl presented on behalf of the citizens of Atlanta. ${ }^{37}$

Ensigns Edward D. Corboy and G. (George) Bowdain Craighill, Jr. arrived at the sprawling northern New Jersey industrial complex ten days after the christening. Besides the Atlanta, they noted a half-dozen destroyers, Atlanta's sister Juneau and several cargo ships in various stages of fabrication up on the building ways. Now moored within a finishing basin adjacent to the Hackensack River, the Atlanta still needed much work. Catching their first glance at their future home, Craighill and Corboy noted that electrical cables, acetylene hoses, and pneumatic gear snaked over the decks as riveters and welders continued work on the ship's interior and exterior. Corboy was impressed: "The sunlight striking her mighty turrets was a stirring sight...it was inspiring to know that the

36 "Launching Report, September 6, 1941 from Building Way Number Eight of Federal Shipbuilding and Dry Dock Company," Atlanta Pre-commissioning folder, Ships History Branch, NHC.

37 “Navy Launches Two Cruisers,” New York Times (7 September 1941), 1, 42. 
ship bearing those turrets was to be the fastest and most graceful cruiser in any navy." 38

Reporting to a two-story building that housed the offices of the precommissioning crew, the two ensigns discovered they were the first naval reserve officers to arrive. About a third of the ship's wardroom had already reported for duty, mostly more senior line officers having Naval Academy commissions.

For the next two weeks the two ensigns participated in daily inspections and tracked the ship's progress. They then found themselves assigned to the Communications Station in New York, reviewing and updating Atlanta's communication publications. Craighill continued to perform this tedious chore as Corboy joined Shaw down in Washington at the gunnery school. When he returned to New Jersey on 3 December, Captain Samuel Jenkins, the commanding officer had arrived. ${ }^{39}$

Much had been accomplished during Craighill's absence. Furniture and flooring were installed along with machinery and electronics. Twice the ship made short cruises in Newark Bay. On 28-29 October, Atlanta left her berth and headed out to sea escorted by the destroyer Dahlgren (DD 187) for her builder's trials. ${ }^{40}$ After a month of adjustments and further equipment installation, it was the Navy's turn to evaluate the ship at sea. In a letter dated 25 October, Admiral Royal E. Ingersoll wrote to Bowen:

As you well know the ATLANTA represents the first of the only modern cruisers built for the U.S. Navy.

Originally intended as a destroyer leader, the fluidity of tactics in the present war has suggested greater usefulness of this type of reconnaissance and new task groups.

Prompt utilization of the possibilities of this type depends on full development of all her characteristics on trials.

The ATLANTA will be the only ship of this type to run complete trials.

For these reasons, it is requested that every effort be made to make these trials as exhaustive and complete as possible. ${ }^{41}$

Subsequently, Atlanta once again headed down Newark Bay on 21 November to cross the Hudson River and up the East River under the Brooklyn Bridge for a drydocking at Navy Yard New York. After a quick hull inspection, the nearly completed cruiser left on the afternoon of the 23rd for an overnight voyage to Rockland, Maine. Arriving there at 1100 to pick up the Navy's trial riders, Atlanta departed and began a series of full power runs of four hour segments, astern runs of one hour duration, full ahead to full back "crashes," and then running tests to standardize shaft turns for 12 knots on up to full ahead. Atlanta developed about 80,000 SHP (shaft horsepower) and reached

38 Technically, Atlanta possessed gun "mounts" versus turrets, the distinction being that light armor protected the 5 inch 38 caliber guns while heavier cruisers had their larger caliber rifles encased in turrets of thick steel.

39 Corboy, "The Log of 'Mighty A," part 3.

40 Memorandum, Box 2, Folder USS Atlanta CL-51 Launching and Trials, Entry 157, RG 80 General Records of the Department of the Navy, NARA, New York.

41 Ingersoll letter to Bowen of 25 October 1941, Box 2, Folder USS Atlanta CL-51 Launching and Trials, Entry 157, RG 80 General Records of the Department of the Navy, NARA, New York. 
34 knots on her best run. On the 27th, she steamed at 30 knots and 25 knots while en route to Boston. After dropping off the trial riders, Atlanta headed back to New York, arriving the next morning.

In his monthly report to Bowen, Federal Shipbuilding's general manager was proud to report that Atlanta completed her official sea trials, "exceeding all requirements without any difficulty, thereby permitting her completion in December 1941, four months ahead of the 36 months contract time, notwithstanding a one month delay from labor trouble in August 1941." He also noted that her fuel consumption was ten percent below guarantees and, "with 40,000 SHP per shaft she is more powerful than any U.S ship except one of the aircraft carriers." Finally he boasted that Atlanta would be "completed ahead of time within cost estimates." 42

On the morning of 8 December the pre-commissioning crew of a dozen officers and 25 chiefs and junior petty officers gathered in the ship's office around Captain Jenkins and together they listened on the radio to President Roosevelt's declaration of war message and the subsequent action by Congress to declare war against Japan. The thought of war must have been sobering for these men who were about to put a warship in commission.

Rear Admiral Bowen was shocked by the Japanese attack. He expressed dismay when he heard that Army radar had detected the attack but the information was not acted on. As the director of the Naval Research Laboratory, he had worked hard to get radar in the field and the outcome at Pearl Harbor made many feel their efforts were for nought. While Bowen ran the shipyard he also retained his responsibilities at the Naval Research Laboratory. Given the outbreak of war, he yearned to focus more of his attention on researching and developing the technology that could win the war. ${ }^{43}$

The attack angered the members of Local 16. On 10 December, Bowen received a supportive letter from President Peter Flynn that enclosed the following resolution:

Whereas the acts of treachery of the Japanese Government have amply demonstrated the desire of the Axis combination to enslave the world with a chain of bondage conceived in the diseased minds of Hitler cohorts.

Be it resolved: That we, the members of Local \#16 IUMSWA - CIO pledge our wholehearted cooperation to the President and the Government of the United States, in the crusade for the preservation of democracy in a world which is being harried and destroyed by the "mad dogs" of the Axis , and may it be further RESOLVED that we, the officers and members of Local \#16 pledge ourselves to land every effort to increase our production of the vital defense vessels so necessary for the

42 "Chronological Schedule of Principal and Governing Events to Effect Delivery by December $31^{\text {st }}, 1941$ " dated 17 September 1941; C.A. Holderness memorandum to Rear Adm. H.G. Bowen, dated 20 October 1941, Box 2, USS Atlanta Folder, Entry 157, RG 80 General Records of the Department of the Navy, NARA, New York; W.C. Hemingway Memo to Bowen of 3 December 1941, Subj: Nov 41 Operations, Box 9 , Harold G. Bowen Papers, Seeley G. Mudd Manuscript Library, Princeton University, Princeton, NJ.

Bowen, 166. 
extermination of the menace which at this moment threatens the security and freedom of the democratic peoples of the world. ${ }^{44}$

For three months the Navy had walked on a tightrope in operating a shipyard and dealing with the union. With Flynn's letter, Bowen saw an opportunity to get the Navy out from under the responsibility for running Federal Shipbuilding.

As officer-in-charge, Bowen had set out to make the operation more profitable and more efficient in order to protect the government from lawsuits by U.S. Steel should the government desire to return Federal Shipbuilding to private hands. Of course to achieve this goal, he needed the support of Local 16, which had hailed him as a conquering hero as the union, but on the assumption that the Navy takeover meant that the Mediation Board ruling would be enforced. Bowen, however, offered that he had no instructions on this issue and sought guidance. Clearly Navy Secretary Knox, the former Republican candidate for vice president, had no desire to implement the Board's ruling. Side stepping the issue, Knox instructed Bowen to refer requests on the union maintenance issue to the "National Defense Mediation Board for such action as they may see fit." $\$ 5$

When Flynn wrote at the end of October to request union consultation on proposed shift changes, Bowen shot back: "My instructions from the Secretary of the Navy in regard to the Kearny plant do not authorize me to recognize any Union or group working in the plant as a collective bargaining agent for the employees."

Meanwhile the Defense Mediation Board did conduct an investigation upon hearing complaints that the Navy was not enforcing their ruling and directed Bowen to fire employees who had not renewed their union memberships. Bowen passed this edict to Knox, telling the navy secretary that only he or the president could direct him to take such an action. Knox chose to stick the board's direction in his desk and ignore it.

That the Union did not pull its members off the building ways is a tribute to Bowen's initiatives to improve workers' conditions. Appalled by the high death rate, Bowen initiated safety indoctrination for new employees and brought in outside consultants to review construction hazards. By constantly walking about the yard, he often nipped problems in the bud and built a respectful relationship with the union leadership and the workers. "Korndorff recognized the union, but didn't meet it socially, while I met the union socially but did not recognize it." ${ }^{47}$

Bowen managed to increase productivity for the last three months of 1941 by 28.41 percent, 22.31 percent, and 38.92 percent respectively in comparison with the second quarter span under private management. With Local 16's patriotic resolution in hand, Bowen suggested to the navy secretary that the time was ripe to return the shipyard

44 Flynn letter to Bowen of 10 December 1941, Box 9 , Harold G. Bowen Papers, Seeley G. Mudd Manuscript Library, Princeton University, Princeton, NJ.

45 Knox letter to Bowen of 18 September 1941, Box 9 , Harold G. Bowen Papers, Seeley G. Mudd Manuscript Library, Princeton University, Princeton, NJ.

46 Bowen, 221.

47 Ibid. 
"while the going was good." Knox readily agreed. On 5 January 1942, President Roosevelt signed an executive order relinquishing control of Federal Shipbuilding and Dry Docking Company. ${ }^{48}$

When U.S. Steel assumed control of the shipyard on 6 January, the newspapers were full of praise for how the Navy operated the yard, noting that during Bowen's tenure, twelve keels had been laid and ten ships launched, including four destroyers and the cruisers Atlanta and Juneau. Knox boasted: "As a result of a recent industry - labor conference there will be no war work stoppages anywhere and all disputes will be resolved by peaceful means." Bowen thanked both union and production personnel at Kearny for his success.

Three days later, Knox scribed to Bowen, "I want to take this opportunity to tell you that I think you did a perfectly splendid piece of work, satisfactory in every possible way, including the question of production. You had to handle a very difficult situation and you handled it very effectively so that the Navy came out with enhanced prestige in spite of the fact that the makings were there for serious trouble." ${ }^{49}$

Unfortunately for Bowen, his dreams of going back to work full-time at the Naval Research Laboratory never materialized as during the war he would seize seven more industrial facilities on behalf of the Navy to assure war production. ${ }^{50}$

However, he could take some solace in that the ships built at Federal Shipbuilding and Drydock Company would contribute to America's victory during World War II. Sadly the two light cruisers Atlanta and Juneau would not survive the year. Friday 13 November would prove to be the last for both ships that were damaged the night before during the naval battle of Guadalcanal. Atlanta would be scuttled in the vicinity of the island having suffering numerous shell and torpedo hits. Juneau vaporized in 20 seconds with hits by two torpedoes fired by a Japanese submarine. Thinking there were no survivors, the remaining American ships departed the scene - in fact there were some hundred men in the water and most did not survive.

$48 \quad$ Ibid., 222.

49 Knox letter to Bowen, Awards Folder, Box 2, Harold G. Bowen Papers, Seeley G. Mudd Manuscript Library, Princeton University, Princeton, NJ.

50 Bowen, 203. 